DOI: $10.15593 / 2224-9354 / 2020.3 .22$

УДК 341.231 .14

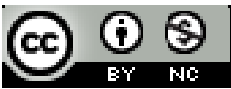

\title{
Fabio Coacci
}

\section{THE GENESIS OF THE CONCEPT OF UNIVERSAL RIGHTS IN THE MODERN ERA}

\begin{abstract}
This review paper investigates the philosophical cum political genesis of the concept of universal rights in the modern era through the examination of the conceptualization of the universal rights in de Vitoria, Grotius, Hobbes, Locke. The main goal is to explain to what extent their conceptions of universal rights are biased by their society of origin and particular interests at stake (in this case, those of the Europeans). That is the reason why, the supposed contribution of this paper is to understand how the current conceptualization of rights carries the legacy of these asymmetric features and, accordingly, to reshape the current conceptualization of (human) rights in order to make them truly universal and, thus, detachable from any particular philosophical traditions and local ethical views.

Keywords: universal rights, Jus Gentium, natural law, natural rights, moral and political demands, particularistic universalism, Francisco de Vitoria, Ugo Grotius, Thomas Hobbes, John Locke.
\end{abstract}

INTRODUCTION - the debated origins of universal rights. Perhaps, the birth of universal rights cannot be dated before the proclamation of the Universal Declaration of Human Rights ${ }^{1}$ which seemed to establish fundamental and inalienable rights as a common standard of achievement for all peoples and all nations and affirmed the faith of peoples of the UN in fundamental human rights. Moreover, other scholars, such as Samuel Moyn, conceive the proclamation of the UDHR «less the annunciation of a new age than a funeral wreath laid on the grave of wartime hopes» $[17$, p. 3] and support the idea that human rights have become a spread powerful set of ideals and a proper cause of justice for people only in the 1970s when «human rights would begin to be invoked across the developed world and by many more ordinary people than ever before» $[17$, p. 4] and with the rise of the international human rights movement ${ }^{2}$. Thus, according to Moyn, human rights were actually born when they acquire a significant political role being effectively adopted as an ideal to strive for by people from all over the world. Moreover, Moyn is also sceptical toward the possibility to understand human rights as the development of prior theories

\section{(C) Fabio Coacci, 2020}

Fabio Coacci - Assistant Lecturer and PhD Student. University of Macerata (Italy), Department of Political Science, Communication and International Relations (SPOCRI); Lecturer and PhD Student, MGIMO University, School of Government and Politics, f.coacci1@studenti.unimc.it.

${ }^{1}$ Hereinafter referred to as UDHR.

${ }^{2}$ In 1977 Amnesty International, as the leading NGO in the worldwide protection of human rights, won the Nobel Peace Prize and in the same year the words "human rights" were printed in the New York Times nearly five times as often in any prior year in the publication's history. S. Moyn, The Last Uthopia: Human Rights in history, p. 4. 
and, so, the interpretation of human rights as a result of an evolutionary process started with seventeenth and eighteenth centuries doctrines of natural rights and the right of man. The main remarkable difference pointed out by Moyn is the fact that natural rights were elaborated in order to justify the construction of state sovereignty, while contemporary human rights have been conceptualized in order to be claimed even against the state sovereignty.

However, beyond the endemic differences of the case due to the evolution of the concept of right, it is possible to find elements in common between the contemporary conception of fundamental rights and previous notions of right(s). The following chapters retrace the main steps of the development of the universalistic character of the notion of right briefly examining the fundamental contributions on this matter of Francisco de Vitoria, Hugo Grotius, Thomas Hobbes and John Locke through the analysis of their studies on the notions of natural law and natural rights.

De Vitoria's primordial universalism of natural rights. De Vitoria is considered one of the first theorists of natural rights as universal individual rights, to some extent explicitly granted to each inhabitant of the Earth. In his work Relectio de Indis he makes a list of fundamental rights, such as the right to sociability and communication (Ius communicationis), the right to move and travel (Ius peregrinandi et degendi), the right to trade with other peoples (Ius commercii), the right to move to other countries and to acquire citizenship (Ius migrandi), the right to property of unused things (Ius occupationis), right to preach and declare the ghospel (Ius praedicandi et annunciandi Evangelium), the right-duty to correct the Indians (correctio fraterna), the right-duty to protect converts from their lords, and the right to defend the own rights with the war [7, pp. 151-160]. Moreover, de Vitoria points out that «the law of peoples (jus gentium) [...] is natural law or is derived from natural law» and «what natural reason has established among all nations is called the jus gentium» [7, p. 151]. Thus, the derivation of the law of peoples from the natural law marks the naturalistic foundation of a universal law and universal rights, which should theoretically be recognized to all persons and peoples, but which are, in facts, drawn mainly on the Spanish concerns. Indeed, the universalistic character of the law and fundamental rights relies on the natural reason which is potentially intrinsic in each person and people and which determines the jus gentium [24] since what natural reason establishes among all the peoples is called jus gentium and many things seem to proceed from the jus gentium which, largely deriving from the natural law, has the power to establish rights and duties [7, p. 151]. In addition, de Vitoria acknowledges the Indian Barbarians endowed with the rational faculties of man so they are considered rational men even though their form of rationality is to some extent lower and limited. Therefore, the natural rights listed in his work are conceived as natural, absolute, and, thus, abstractly universal rights, of which Indian Barbarians should be entitled to, but which are drafted in a showily asymmetrical and concretely unequal way in order to protect the Spanish interest and conquest [9]. 
Not only do the Spanish can recourse to war because the Indian Barbarians, the perfidi hostes, are violating their rights, such as the right to migrate and trade, but also to uphold the rights of Indian Barbarians from the tyrannical law which offend them:

Another possible title is founded either on the tyranny of those who bear rule among the aborigines of America or on the tyrannical laws which work wrong to innocent folk there, such as that which allows the sacrifice of innocent people or the killing in other ways of un-condemned people for cannibalistic purposes. I assert also that without the Pope's authority the Spaniards can stop all such nefarious usage and ritual among the aborigines, being entitled to rescue innocent people from an unjust death [7, p. 159].

Thus, the denial of some absolute rights of which a person cannot renounce can be a legitimate cause for the just war. Therefore, according to de Vitoria the just cause are not the sins related to the violation of the natural law, but rather the violation of individual rights since Barbarian Indians can be eradicated because of they are causing harms to men. However, even though de Vitoria's recognition of rights to Barbarian Indians led to legitimize their extermination by the Spanish, his theoretical contribution to the universalism of rights and to the concept of individual right cannot be denied as he outlined a list of fundamental rights and he ascribes them to all men.

The validity of natural law etsi deus non daretur. Another scholar which fosters the development of the natural rights as universal individual rights and, thus, of the universalism of the foundation of rights is Hugo Grotius. In the wake of Francisco de Vitoria, Grotius, which is the author of the definition of the ius as qualitas moralis of the man, believes that the rights of man are founded by the natural law, which in turn expresses the appetitus societatis, which are proper to all men [2, $\mathrm{p}$. VI]. As the source of the natural law expresses something which is proper to all men, in the same vein all men are recipients of the natural law and holders of natural rights [3, p. 10] This position had strengthened the individual and universal character of natural rights and had established the bases for the contract theory, which would have been adopted and amply developed by preeminent authors such as Thomas Hobbes and John Locke, and later, among the others, Jean-Jacque Rousseau, Immanuel Kant and John Rawls, insofar as people are led to establish a social life in compliance with the human rationality with which all men are endowed. However, his main contribution is probably the implicit original attempt to secularize natural rights conceiving a moral foundation of natural rights which relies on human rationality rather than on religion. Indeed, in the first book of his main work De Jure Belli Ac Pacis he states that «What we have been saying would have a degree of validity even if we should concede that which cannot be conceded without the utmost wickedness: that there is no God, or that the affairs of men are of no concern to Him» $[11$, p. 4]. Even though Grotius does not deny that the natural law ultimately comes from the God, he admits that the natural law would be valid etsi deus non daretur, 
that is as if God did not exist, since the nature of the man is the rationality which makes them able to realize the natural law. Thus, the human rationality is conceived as the source of the natural law and natural rights which would conserve their validity even if the God would not exist. His innovative thought marks a shift from the classical naturalism, which based the natural law and natural rights on the religion, to the modern naturalism, which replaced the religion with the human reason as the element of foundation of the natural law and natural rights. To some extent, Grotius can be conceived as an ancestor of the reorientation of the conceptions of justice and rights which Rawls sums up with the phrase «political not metaphysical» [20]. However, still, beyond his cutting-edge assumptions about the natural law and rights and his innovative reforming principles for the governance of international relations, Grotius' conceptualization of natural rights and natural law is biased towards the interest of the European sovereigns. Indeed, he theorizes the natural right to occupy uncultivated lands [11, p. 101] and the legitimacy of the military intervention by sovereigns to punish weighty violation of natural law and jus gentium, including the cases in which the violation (iniuriae) does not regard the sovereign or his subjects. Clearly at odds with de Vitoria's assumptions, Grotius maintains that the war is just also against those who do not respect their parents or eat human flesh [2, p. 28].

After Grotius, the other main social contract theorists of the early modern period Thomas Hobbes and John Locke make relevant contributions on the development of the concepts of universal and individual rights, even if they continue to refer to the notions of natural law and natural rights.

Natural rights as individual rights. The classical formulation of the concept of individual right can be attributed to Thomas Hobbes thank to his contraposition of law and right, lex and ius, duty and freedom [14, p. 80]. In the Hobbesian naturalistic foundation of rights, the universalism of the rights-holders and the universalism of the foundation of rights tend to identify themselves in the same conception: «every man has a right to every thing, even to one another's body» [14, p. 80] The right of every man to everything in the state of nature is based on the principle of self-preservation which is valid for each man and, since it is supposedly demonstrated with the same scientific rigour of mathematical theorems, has to be recognized by everyone [13]. The rights which resulted from this principle are natural rights whose holders are all men as such. Hence, a rationalistic paradigm of universal individual rights is firstly drafted. Moreover, according to Hobbes «a law of nature, lex naturalis, is a precept, or general rule, found out by reason» and «the right of nature is the liberty each man hath to use his own power as he will himself for the preservation of his own nature; that is to say, of his own life; and consequently, of doing anything which, in his own judgement and reason, he shall conceive to be the aptest means thereunto» $[14, \mathrm{pp} .79,80]$ reaffirming the assumption that human reason is the foundation of natural law and natural rights. Furthermore, in Hobbes, the radicalization of the individualistic aspect of natural rights, conceiving them in term 
of natural liberty and power, leads to a preeminent role of the concept of natural individual rights, of which the natural law is the derivative one. Rights are power and liberty of the individuals and for this reason they can be completely transferred to the sovereign which becomes the legitimate holder [2, p. 28] and which has absolute power over its subjects since it is the only body able to ensure peace among people and to avoid the condition of Bellum omnium contra omnes, i.e. the war of every one against every one, which distinguishes the state of nature. Hobbes also argues that the conditions of savage people in many places of America are close to this kind of state which make them live at permanent risk [14, p. 78]. Moreover, since the sovereigns are all independent, the relations among them is also similar to the state of nature and, thus, the protection of individual rights, of both subjects and foreigners, mainly becomes a matter of the sovereign.

The inalienability of fundamental natural rights. The social contract theorist John Locke seeks to correct the alienability and transferability of the rights and, to this aim, reconsiders the property as a natural right, which, instead, was not for Hobbes. The term properties $^{3}$ is used by Locke to identify those fundamental, so not alienable and transferable, rights - the right to life, to freedom, and to property which are already in force in the state of nature and they are to some extent effectively enjoyed. A fourth right is the right to punish who violates the above-mention rights since the natural law prescribes the protection of these rights. Thus, fundamental rights cannot be transferred to the State, rather the latter is precisely committed to protect these fundamental rights [2, p. 28]. Even though in Locke there is a return to the prominence of the natural law on the natural rights, while the foundations remain always the rational humanity [15, p. 107], natural rights are provided with a wide and deep protection. Indeed, with the social contract only the fourth right, the right to punish, is transferred to the Sovereign while the other rights are considered inalienable [15, p. 115]. Thus, Locke makes a list of fundamental rights which also the Sovereign is obliged to respect, otherwise men have the right to resistance, the so-called appeal to Heaven:

As there can be none between the legislative and the people, should either the executive or the legislative, when they have got the power in their hands, design, or go about to enslave or destroy them, the people have no other remedy in this, as in all other cases where they have no judge on earth, but to appeal to Heaven; for the rulers in such attempts, exercising a power the people never put into their hands, who can never be supposed to consent that anybody should rule over them for their

${ }^{3}$ The concept of properties of some fundamental rights can be conceived as a rudimental expression of the recent concept of the right to have rights fostered by Hannah Arendt and Stefano Rodotà since both terms underscores the effective enjoyment of some rights entitled to each human being, in the second case including also collective rights, which are jeopardized by the overwhelming power of the sovereign in the modern era and by the imbalanced distribution of powers and private actors in the contemporary age. S. Rodotà, Il diritto ad avere diritti. 
harm, do that which they have not a right to do. And where the body of the people, or any single man, are deprived of their right, or are under the exercise of a power without right, having no appeal on earth they have a liberty to appeal to Heaven whenever they judge the cause of sufficient moment. And therefore, though the people cannot be judge, so as to have, by the constitution of that society, any superior power to determine and give effective sentence in the case, yet they have reserved that ultimate determination to themselves which belongs to all mankind, where there lies no appeal on earth, by a law antecedent and paramount to all positive laws of men, whether they have just cause to make their appeal to Heaven [15, p. 179].

Therefore, not only does Locke affirm, in contrast with Hobbes, that there are some inalienable rights which cannot be transferred to the Sovereign but he also conceives this fundamental meta-right, the appeal to Heaven, which enables men, once the civil society has been set up, to avoid to respect the positive laws enacted by their rulers. Each man is entitled to this meta-right since persons have reserved the ultimate determination to themselves which belongs to all mankind. However, even though Locke describes the «just cause» to make the appeal to Heaven consisting of the violation of fundamental rights of man and the abuse of the right to punish by the constitutive power, he fails to specify the means through which men can force the rulers to respect the fundamental rights they are violating. In any case, his contribution to corroborate the protection of some fundamental rights and the status of men as rights-holders is evident. In his appeal to heaven it can also be searched out that one's own right can also be claimed against the state which presumes that beyond the positive and legal rights there are basic and natural (moral) rights which, thus, are not only those recognized by the settled rules [8]. Moreover, beyond the property of men to his own person and fundamental rights, Locke is also able to provide an explanation to the right to private property which had been a longstanding issue since the earth was to be conceived something in common to all men. Locke claims that the labour of his body and the work of his hand are the mean by which a man can get the property of something since his work embodies the natural thing appropriating it and increasing its intrinsic value [15, p. 116]. However, Locke points out that one can get the property of something «at least where there is enough, and as good left in common for others» [15, p. 116]. This specification leaves space for mitigation of the right to private property, which would not be considered a natural right tout court as for the right to property, and seems to set a valid limit to the appropriation of things since it has to be done in respect of the same right of others. In his work, he also dedicates ample space to the question of the new world, along with its inhabitants, the «wild Indians», and their conquest, reaching the same conclusion, even though through slightly different justifications, of his predecessors: the occupation of America, the war conducted by the Europeans and the extermination of the wild Indians are rightful. Even though Locke admits an «equality of men by Nature» [15, p. 106], several elements downgrade the American Indians to a lower 
level of civilisation. The organization of their communities is not comparable with that of a political society [15, pp. 151, 152], their condition is similar to the state of nature $[15, \mathrm{p} .125]$ and their laws and attitudes in violation of the natural law and, for the latter reason, they can be exterminated [15, pp. 109, 110]. Even the Indians' unproductivity of the work infringes the natural law since the waste of land is an injustice against the whole mankind and a violation of the divine rule to make it productive. In order to fight this injustice and make the waste land productive, English people are legitimized to make war to American Indians and to occupy their territories [18] even if it implies the grave violation of the fundamental right to life [25, p. 33]. It is clear that even in Locke a theory of the equal universal enjoyment of rights is compounded with a theory of cultural inequality which turns to be a theory of spoliation and subjugation [2, p.31].

Natural law and rights as moral concerns. For the main purpose of this work, i.e. the analysis of the contributions of the above-mentioned authors in the development of the concept of universal right, it is worth to mention Thomas Pogge's analysis of the common features of natural law, natural right and human rights looking at them as moral notions. Pogge maintains that even though human rights are a quite new concept in the history, as a moral notion it has evolved from earlier concepts, that is the natural law and natural rights. Indeed, according to Pogge «all three concepts have in common that they were used to express a special class of moral concerns, namely ones that are among the most weighty of all as well as unrestricted and broadly shareable. These four common features of the three concepts constrain not the content of the select concerns, but their potential status and role» $[19, \mathrm{p} .60]$. These three concepts are a special class of moral concerns insofar as their uses can be conceived «as making moral demands on human conduct, practices, and institutions» $[19$, p. 60]. Being understood as concerns common to the whole mankind, they can potentially be claimed by anyone against any other person or institution which have the moral duty to respect them. Their significant weight derives from the fact that their respect is paramount in comparison to other moral and nonmoral concerns. As we have seen in Locke, the respect of natural rights is so preeminent that the violation of some fundamental rights may legitimize the individual to appeal to heaven and, thus, to act in contrast with the constitutive power. Therefore, both individuals and social institutions ought to respect these moral weighty demands. At the same time, these moral concerns are conceived as unrestricted in the sense that «whether persons ought to respect them does not depend on their particular epoch, culture, religion, moral tradition, or philosophy» $[19$, p. 60]. Thus, the unrestricted characteristic of these moral demands makes them potentially relevant for persons and peoples of any time and place and provides an inclusive openness which strengthens their attractiveness - an element which is linked to the fourth feature. The broad shareability of these moral demands consists of their capability to be «understood and appreciated by persons from different epochs and cultures as well as by 
adherents of a variety of different religions, moral traditions and philosophies. [...]. The shareability of moral demand is, then, a function of how widely it can be shared across persons and cultures and of how accessible it is to each of them» $[19, \mathrm{p} .60]$. Thus, the possibility of these notions to be easily and broadly shared by as many persons as possible is related to their capability to be understood and appreciated by persons and peoples regardless their cultural, philosophical and religious background. The concepts of natural law and natural rights, as conceived in western fifteenth- through eighteenth-Century philosophical and political tradition partially embrace these features, however they are drawn according to the parochial considerations and concerns of a particular group of people. This is not to say that a theory elaborated in a particular part of the world in the framework of a specific culture and philosophy cannot be shareable, and thus universal, as such, but rather that it can be able to be widely shared if, and only if, is detachable from any particular epoch, culture, religion, moral tradition, philosophy and any particular consideration, interest and concern. Even if the notion of right as a moral concept has been able to become more unrestricted and shareable over time, it is questionable whether it has been completely purified by any particularism and factionalism, which would endanger its shareability. This is the focal question to which this paper has aimed to provide an answer.

Beyond these mild continuities, Pogge catches a relevant shift from natural law to natural rights, which has already been mentioned in the previous paragraphs, that is the conceptualization of the man as a right-holder:

expressing moral demands in the natural-rights rather than the natural-law idiom involves a significant narrowing of content possibilities by introducing the idea that the relevant moral demands are based on moral concern for certain subjects: rightholders. By violating a natural right, one wrongs the subject whose right it is. These subjects of natural rights are viewed as sources of moral claims and thereby recognized as having a certain moral standing and value [19, p. 61].

This shift in terminology implies a rise of the individual which is recognized as bearer of moral claims and demands which other persons are obliged to respect. Violating the natural rights means not anymore wronging the God or lacking rationality but rather wrong other subjects. Thus, the natural law becomes to some extent subordinate to the fundamental natural rights and it is conceived as a means to recognize and enforce them. In this way, the rules of the society become more intersubjective and interrelational insofar as the concept of natural rights involves moral demands on one's conduct toward other subjects and the law has to be respected in order to uphold subjects' natural rights. Therefore, the above-mentioned shift in terminology is also a shift in the content of unrestricted and broadly shareable moral rights which would have received even greater impulse with the shift from the notion of natural rights to human rights' one. 
Conclusion: A particularistic universalism. Even if the above-mentioned authors focus mainly on the notions of natural law and natural rights, these concepts can be conceived as the forerunners of the contemporary fundamental rights since the theories and the studies of the authors analysed in this article have made a noteworthy contribution to the theoretical evolution of the concept of universal rights. However, the universalism sketched out by de Vitoria, Grutius, Hobbes and Locke is clearly developed in compliance with the interests of a particular group of people. Indeed, their universalism ends up to be built on the concerns of the Europeans and to legitimize the conquest of America at the expense of the fundamental rights of the American Indians. The particularistic declination of this universalism, which has proved in action to be deeply discriminatory, partisan and asymmetric, is probably its main shortcoming and may be an aspect of which neither the more recent concept of human rights has been able to get rid of.

\section{References}

1. Baccelli L. Il particolarismo dei diritti. Jura Gentium. Rivista di filosofia del diritto internazionale e della politica globale, 2005, available at: https://www.juragentium.org/topics/rights/it/baccelli.htm (accessed 20 April 2020).

2. Baccelli L. I diritti dei popoli. Universalismo e differenze culturali. Laterza, Lecce, 2009.

3. Bobbio N. L'età dei diritti. Einaudi, Torino, 2005.

4. Chumakov A.N. Thinking in time: Lessons from the history of globalization. Studia Diplomatica. The Brussels Journal of International Relations, 2013, vol. LXVI, no. 1, pp. 93-99.

5. Chumakov A.N., Ioseliani A.D. Philosophical problems of globalization. Moscow, University Book, 2015.

6. Chumakov A.N. Metaphysics of globalization: Cultural-civilizational context. 2nd ed. Moscow, Prospect, 2016.

7. De Vitoria F. Relectiones theologicae XII. De Indis et de Ivre Belli relectiones. Ed. E. Nys. Available at: http://legalhistorysources.com/Law508/VitoriaDeIndis.htm (accessed 24 April 2020).

8. Dworkin R. Taking rights seriously. Cambridge, Harvard University Press, 1977.

9. Ferrajoli L. La sovranità nel mondo contemporaneo. Laterza, Bari, 1997.

10. Gambino A. L'imperialismo dei diritti umani. Caos o giustizia nella società globale. Roma, Editori Riuniti, 2001.

11. Grotius H. De iure belli ac pacis. Neff S.C. Hugo Grotius on the law of war and peace: Student edition. New York, Cambridge University Press, 2012.

12. Fillipov A.F. The vitality of Hobbes' Philosophy. The Russian Sociological Review, 2009, vol. 8, no. 3, pp. 102-112. 
13. Hobbes T. De Cive. Torino, Aragno Editore, 2018.

14. Hobbes T. Leviathan. Hay R. (ed.). McMaster University Archive of the History of Economic Thought, available at: https://socialsciences.mcmaster.ca/econ/ ugcm/3113/hobbes/Leviathan.pdf (accessed 28 April 2020).

15. Locke J. Two Treatises of Government. Awnsham Churchill. Hay R. (ed.). McMaster University Archive of the History of Economic Thought, available at: https://www.yorku.ca/comninel/courses/3025pdf/Locke.pdf (accessed 04 May 2020).

16. Marey A.V. About commonwealths, kings and laws: Franscisco de Vitoria and his lecture "On the civil power". The Russian Sociological Review, 2013, vol. 12, No. 3, pp. 41-51.

17. Moyn S. The last utopia: Human rights in history. Cambridge, Harvard University Press, 2012.

18. Parekh B. Liberalism and colonialism: A critique of Locke and Mill. Pieterse J.N., Parekh B. (eds.). The Decolonization of Imagination, London, Zed books, 1995.

19. Pogge T. World poverty and human rights. Cosmopolitan Responsibilities and Reforms. 2nd ed. Cambridge, Polity Press, 2008.

20. Rawls J. Justice as Fairness: political not metaphysical. Philosophy and Public Affairs, 1985, vol. 14, no. 3, pp. 223-251.

21. Rodotà S. Il diritto ad avere diritti. 10th ed., Laterza, Bari, 2012.

22. Taylor C. Conditions of an unforced consensus on human rights. Bauer J.R., Bell D.A. (eds.). The East Asian Challenge for Human Rights. Cambridge, Cambridge University Press, 1999.

23. Tedesco F. Diritti umani e relativismo. Laterza, Roma-Bari, 2009.

24. Tierney B. The idea of natural rights. Cambridge, B. Eerdmans Publishing Co., 1997.

25. Tuck R. The rights of war and peace: Political thought and the international order from Grotius to Kant. Oxford, Oxford University Press, 1999.

Оригинальность $83 \%$

Получено 17.02.2020 $\quad$ Принято 10.03.2020 


\section{Ф. Коаччи}

\section{ГЕНЕЗИС КОНЦЕПЦИИ ВСЕОБЩИХ ПРАВ В СОВРЕМЕННУЮ ЭПОХУ}

В обзорной статье исследуется философский и политический генезис концепции универсальных прав в современную эпоху посредством изучения концептуализации универсальных прав в Де Витории, Гротиусе, Гоббсе, Локке. Основная цель состоит в том, чтобы объяснить, в какой степени их концепции универсальных прав предвзяты в отношении их общества происхождения и конкретных интересов (в данном случае европейцев). Вот почему предполагаемый вклад этого документа состоит в том, чтобы понять, как текущая концептуализация прав несет в себе наследие этих асимметричных особенностей, и соответственно изменить нынешнюю концептуализацию прав (человека), чтобы сделать их действительно универсальными, и таким образом, отделяется от каких-либо конкретных фрилософских традиций и местных этических взглядов.

Ключевые слова: универсальные права, Jus Gentium, естественное право, естественные права, моральные и политические требования, партикулярный универсализм, Франсиско де Витория, Хьюго Гротий, Томас Гоббс, Джон Локк.

Фабио Коаччи - преподаватель и аспирант, Московский государственный институт международных отношений (университет) Министерства иностранных дел Российской Федерации, факультет управления и политики (ФУП), ассистент преподавателя и аспирант, Университет Мачерата (Италия), кафедра политологии, связи и международных отношений, e-mail: f.coacci1@studenti.unimc.it.

Received 17.02.2020 Accepted 10.03.2020 Published 28.09.2020 